\title{
Strategy Character Building of Students at Excellent Schools in the City Of Banda Aceh
}

\author{
Djailani AR \\ Jurusan pendidikan fkip Universitas Syiah Kuala Banda Aceh 23111
}

\begin{abstract}
Individual behavior is displayed in the daily manifestations of the individual's own spiritual condition and the phenomenon is called the character, morals, manners, personality, character, temperament, or habit. Character building of students in the school can be done through the process of learning or habituation-conditioning and the provision of exemplary teachers. The study aimed to gain insight about it strategies implemented by principals and teachers at top schools of Banda Aceh. Method descriptive using by qualitative approach, observation, interviews, and documentary study. The subjects principal, teachers and students are determined based on the purpose of the study, processing data with qualitative analysis. The results indicate that the principals and teachers at the excellent school in the Banda Aceh implement student character building by using the following strategies: Provides an understanding of the character/personality of the students, developing Islamic culture in schools, character building through special forums, exemplary, sanctions for students who violate. Based on the results of the study were formulated following suggestions: Pattern is applied to character building excellent schools should continue to be maintained as it is quite successful, Teachers and educational staff in the excellent school should keep perform as role models for students in appearance, behavior, and attitudes.
\end{abstract}

Keywords: Coaching, provide, qanun and character development

\section{Background}

\section{Introduction}

These days we often hear of violence, crime, and delinquency both by the students, who were formerly very rare happening on bumi serambi mekkah or special area known as local Acehnese shari'a. This phenomenon occurs continuously in small scale and large scale, and impressed carried out systematically and systemically. Even the violence also starts reaching all levels of society, including academics in universities who have a professional degree. All the phenomena mentioned above now seems to be a spectacle of the whole population of the country so as to give a bad image about our image as a nation once known to be friendly, like mutual assistance, life is full of tolerance and harmony, as well as people who love and live in harmony, and cultured. Even a very concerned is the phenomenon of crime, violence, immorality, and various other dishonorable behaviors also occurred at students.

This condition is a major concern for educators, government, parents and community leaders, as they are easy generation who will inherit the leadership of the nation in the future. Loss of character/personality of the younger generation means we will lose in the future leaders of the nation, or the state will be led by a generation that is not character, moral and ethical. All parties believe there is not a nation to grow and develop into a developed nation if the nation was led by people no character/personality is good.

The occurrence of various crimes, violence and immorality primarily done by the students, identified as a crisis of personality or character of the students, as a result of an education system that gives less attention to the efforts to inculcate noble values for the character of students. In other words education undertaken for failure to cultivate virtue or moral character formation of students. Noble values are inculcated and socialized through school, did not seem to enter into self-learners.

Character or Character Building implemented but achieving less likely fall into "teaching values" normative-doctrine, which is only a drop in the student's head for a while before and during the tests and subsequently evaporated never goes to the liver, and form personality. That is, what is learned in school is not in place in order to develop a personality, but merely to meet the demands of formal-academic, for example: to get the values and get a diploma that is used to meet the formal requirements for entering higher education and to entering the workforce.

Failure of character/personality in schools has caused many negative effects for the personality of students. This is due to the education process does not touch the bottom of conscience so that students provide experiences that develop awareness of the importance of character in his life. As a result, their behavior does not grow and develop in the direction of human behavior, but still on the level of natural instinct like animals. They were only oriented to the fulfillment of the desire to eat (eating), mating (mating), sleeping/relaxing (sleeping), fighting/selfdefense (defending) [1]. 
The standard is human after all, merely orientation on human values are low, that the acquisition "semart" (treasure-riches and pleasures), "rank" (position-power and pleasures), and "degree" (honor, prestige, reputation, fame, glory, and all the pleasures). So, it seems our education situation in the last 35 years growing awareness of the less noble values (spiritual aspect), which became the driving force development of learners towards human life and even the direction of the super-human life (divine) [2].

If you listened to the educational process in the school there are some conditions that lead to Character Building has not succeeded in building character of students to prevent misconduct, namely; First, education increasingly shallow at both the goals, processes, outcomes and sectoral level. This means that education should be directed to achieve perfection in life, it is a goal-directed narrowing, which is only to get the infrastructure to be able to live in affluent economic solely. Second, going educational process visualization, meaning that on the surface seems to be run by education seriously, but the process that happens in it is very minimalist. For example, we have seen, early in the morning the streets are filled with students going to school, at school, classes are full of students who take the lesson, the class teacher did not seem to stop talking, explain something, according to the task. But how much knowledge can be absorbed by the student, how proficient skills he mastered for months to learn, how much influence on their behavior after they get out of class or after school has not been a serious concern for all parties. Third; At the level of content-matter, there is over-excessive load for the students and teachers for many subjects in each week. Of course it's difficult and hard for the student to be able to digest it well established and take the point. Similarly, for teachers, a heavy burden that makes it unable to prepare and implement optimal learning. Fourth; At the level of the result, there have been minimized, which means that the quality and quantity of material that can be absorbed by his increasingly declining, both in the cognitive, affective and psychomotor, the quality of the education it seems farther away from the ideal alias increasingly disappointing. Fifth; At the sectoral level appears once the emphasis is increasingly focused on the formal education sector and more narrowed again in the economic sector, to meet the demands of the labor market and economic needs. The informal sector is now much neglected and uncultivated, the result is that the educational character or Character Building be considered insignificant and ignored. In fact, the informal sector is a central sector, which is to establish and develop the personality of young people.

There is more extreme opinion stating that the failure in the character building of students so that the moral crisis in Indonesia was caused by a system of education that is less conducive. In [3] "The moral crisis that occurred in the Earth Indonesia is inseparable from education systems that support all efforts towards the achievement of educational goals, as it is always nice in the Guidelines formulated and vision-mission of any educational institution that is".

In the view above that the main cause of unsuccessful character building of students because the education system is still implemented centrally, not fully granted autonomy to schools, although education reform has long proclaimed. The entire device had been formulated at the center of education, from curriculum, Outline of Teaching (OT), textbooks, and other implementing instructions. Then dropped to the areas to be implemented. Furthermore, the strict controls implemented in the administration of its implementation, and it seems only the administrative component of our education quality benchmarks.

Therefore, if we want education returned to the right track, it is necessary to coaching mind set of the officials in charge of the education sector, rather than simply changing the curriculum, textbooks and facilities. Irregularities in the mindset of officials and managers of education are a source of problems for this is untouchable is the mental attitude. Based on the above reviews it can be concluded that for future moral education/ character or personality should be the baseline building the character of the students so that they are ready to be a reliable man in the mastery of science and technology and has noble manners. In this way you can restore the role of educational institutions or schools and coaches as forming national character in the future. It also encourages authors to conduct a study about system building character/personality that is implemented in schools ahead of Banda Aceh.

Based on these results the authors will devise a strategy coaching character / moral or character to be applied to all educational institutions to prevent violence, crime, delinquency and commendable behavior in school. Habits of doing well in school are believed to be an impact on the behavior of students in family and community life someday. This strategy will be able to fulfill the mandate of the Aceh Qanun education [4].

\section{Formulation of the Problem}

Based on the background of the problems described above can be formulated in this study focus on the problem as follows: "What strategy character building of students who applied to the excellent schools in Banda Aceh"

\section{Research Purposes}

As for the goals to be achieved through this study as follows: To get a complete picture, clear and up to date on character building strategies are applied to the excellent schools in Banda Aceh, both boarding school 
and excellent schools are not boarding.

\section{Theoretical Framework}

1. Character Building

a. Understanding of Character Building

In Indonesian literature, many terms are used which means the same as the character, "character, personality, morality, morals, character, nature, habits and temperament. Implement character building meaning to commit an act or attempt to humanize humans. Character Building is a prophetic vision, as stated in a hadith which means: "I was not sent to this earth except to improve morals".

Character Building is essential for humans, the main reason is because people come to earth not only to take care of him alone, but God also gave the task caliphate (the leadership) to humans for the welfare of human beings and other creatures. This is as stated by [5] namely:

Place of humanity in the face of this earth is seen as the caliph of God, it must have a qualifying mental-spiritual, intellectual and physical high, to be able to manage, utilize and conserve natural resources buried within, above and below the earth of its own. Islam requires that its adherents are able to maintain, manage and develop the welfare of the planet earth for earthly life as a preparation for life in the hereafter.

The educational goals set out [6] as follows: "The purpose of education is to make students complete human being perfect or complete human being. Achieving perfection is shown by the formation of "personal morality" or moral character ". In relation to Character Building [7] asserts about the consequences of the implementation of the Character Building/values as follows:

So if education is carried out consistently, every school should be directed to the purpose of establishing moral individuals. Are moral individuals who have the ability to manage their lives according to the noble values of humanity. Ability as it is on the conscience that has reached maturity. Then all efforts aimed at fostering conscience must be directed so that learners have a sensitivity and appreciation of noble values.

Referring to the above definition can be formulated education means understanding Character Building is an effort to help the students to develop the psychological aspects so that he is able to relate and work with all stakeholders in mutually agreeable conditions. Only by having a character/good moral person can work together and support each other in the performance of its duties.

In [5] psychological targets that need to be developed in a balanced, harmonious and aligned in an effort to grow the character/personality that is both:

Cognitive abilities are centered in the brain (head) in the form of reasonable intelligence, abilities and affective emotions centered on the chest (heart), and the ability to work lies in the hands (hand). A person's character is determined by faith and Godly, and then education is the values of faith and devotion should be a pattern of Character Building.

Integrating noble values to shape the character/personality of the students summed up the dominant religion in education subjects. Religious education aims to enhance human morality, and human beings who are capable of creating a harmonious relationship between citizens. This is confirmed by [8] as follows: "The role of religion is to conditioning the liver, which is to mediate in ethnic conflict or in celebration of those moments when the relationship between the people who do not know each other, even the clergy filled with human values".

The above statement is confirmed again by Karen Penner in [9] which states: "Religion beyond the ebb and flow of human progress and the various events, as well as absorbing modern science while ignoring the existing currents of secularism". The above statement implies that Character Building can be integrated in the subjects of religious education in schools.

\section{b. Character Building Goal}

In simple has stated that the purpose of education is to make human adult learners and responsible as individuals, members of society and as citizens. While more operational [6] as follows: "The purpose of education is to make students" whole man perfect "or" complete human being".

About the enlightened one by [7] is: "The achievement of "perfection" is indicated by the formation of "personal morality" or "moral character". The second view of the above it can be concluded that, if implemented consistently education, then education should be directed to the formation of moral individuals. Personal meaning moral individuals who have the ability to manage their lives in accordance with the demands of human values. While the capability exists only in conscience that already have the maturity.

In the implementation of Character Building to students must be believed that "man was created to worship God. God says, and I did not create the jinn and mankind except to worship me ". Worship God is to surrender himself totally a servant in a Creator God - this is a man's character as "a personal spiritual".

In [10] suggested the subject matter objectives are as follows:

1. Implemented to guide the education of children up to three skills, 
a. The ability to support themselves (ability to make a living)

b. Ability to live meaningfully (ability to live a meaningful live)

c. The ability to participate glorify life (ability to contribute to the ennoblement of life)

2. Education contains subject matter that should be used to achieve these objectives, there are four types of educational material that should be integrated in the agenda of Islamic education, namely:

a. Knowledge are seeded through learning activities (teaching).

b. Skills, which is fostered through training (training)

c. Wisdom, which is grown and raised by education (education)

d. The ability to support themselves (ability to make a living)

Based on the above it can be concluded that education in general is to guide young people to have the ability to be an adult and be able to apply moral values in life, then education should give students the knowledge learned, what skills should be trained, and the value of characters that must be lived.

About the subject matter that needs to be packaged nicely in the process of Character Building are 20 kinds of noble values on self-learners as stated by [11] in his book Character Building for Teens.

\section{c. Character Building Strategies}

Fostering or shape the character of the students cannot be done quickly or instant as it seems. He needs time and a long process as we invest or invest in a business. Maybe one day not to invest would be rich except with the concept of gambling. To get a return on investment of time and the long process of developing new investment and make it big and become rich investment perpetrators.

Character education or moral character is formal as other subjects taught to students certainly do not achieve optimal results. The main reasons are as stated by [12] as follows:

Because the student disposition is not well established, so the inner is not open and not ready to accept the values offered. The disposition is determined by many actors, both internal and external. Internal factors that determine the disposition is, intention, motivation, attention and concentration towards the pupil. While external factors are posture and sitting position, spatial, and dynamic relationship between the subjects involved.

According to experts on the success of character education is largely determined by factors that classroom conditions laid out by teachers when implementing learning education. Teachers are required to build a preposition students to be ready to accept the values offered teachers, if not the consciousness itself is not moved at all, all moral concepts or characters that should be included in the affective and psychomotor domains instead entered in the cognitive realm. He memorized all the noble values, all the good behavior he knew, all the reprehensible behavior is understood, but not manifested in behavior.

Factors that influence the disposition can be grouped into two groups, namely the group consisting of intention-internal motivation, attention and concentration of students and external groups that attitude, posture, spatial, and dynamic relationship between the subjects involved. Internal conditions as stated above is only suitable for teaching cognitive subject through lecture method, while the internal setting can encourage students to always behave according to the setting that was developed and eventually became accustomed to good condition.

Character education for students running over time because of character or moral grow and evolve with the development of students' good behavior and habituation continuously. What we do and what we say every day, how we behave in their dealings with others will eventually grow into the character and can be applied permanently.

In relation to attitudes that need to be developed suggested 7 habits that we need to do it consistently and full of character and commitment to build a strong personal integrity are:

1. Always keep promises

2. demonstrate consistency

3. Always keep commitments and responsibilities

4. The words with deeds

5. Honesty and openness

6. Discipline and respect time

7. Keeping the principles and values that he believed

One of the well-known phrase and should be of note are: "Character is like a tree, and reputation is like its shadow. A shadow is what we think of it, the tree is the real thing"

\section{Excellence School}

a. understanding of excellence schools 
Schools excel in our education system as a very promising model for success in improving the quality of education. Nature of education is changing the culture. Every school has a culture of schools (school culture) is a set of values, beliefs, and habits that have been ingrained, implemented, developed and maintained since the school stands. School implement excel without the courage to break the habit, especially negative ones, whatever model of education and legislation enacted, it will be difficult for us to improve the quality of education.

There are conditions that assist the government in developing superior schools, namely: (1) the parents assume that schools are responsible for educating students, (2) parents believe that the IPA program is more prestigious than the IPS program for their child, (3) the parents believe that the less prestigious vocational schools, (4) the public believes that the title is a symbol of social status. In the international literature all these names commonly called the lab school, effective school, demonstration school, school experiment, or accelerated school, and the schools were advertised with the magnetic attributes.

Among the listings are frequently used vocabulary is effective superior school or school based on the belief that students, regardless of ethnicity, economic status, and gender, will be able to learn in accordance with the demands of the curriculum. The approach adopted is collaborative planning among teachers, administrators, parents, and community. Students are achievement data used as a basis for continuous improvement of the system. Thus a superior school has a number of characteristics that distinguish it from other schools, namely:

1) The vision and mission of the school is clear

2) High commitment to excel.

3) Leadership qualified.

4) The opportunity to learn and setting clear time.

5) Safe and orderly environment.

6) A good relationship between home and school.

7) Monitoring student progress on a regular basis.

Superior school model as described above will manifest them when school is not exclusive tub ivory tower, but to grow as a part of the community so that her conscience had sensitivity to the community (a sense of community).

\section{b. Superior School Development Strategy}

Superior schools or school effective is certainly the desire of all people, to achieve a position of superior schools is certainly needed the right strategy. In this case, director-general of education Indonesia presents a strategic concept for superior towards the school, which is effectively managing the school management. An area of school management that needs to be organized in order to develop a superior school is school management. Can be explained in detail the various dimensions of the superior schools and its relation to the management and organization. School concept superior views of the dimensions of school management can be described as follows:

\section{School Management,}

Understanding the management itself can be explained by understanding that presented by experts are [9] "Management is the process to achieve the objectives of the organization with activities in four main functions, namely planning, organizing, leading, and control. Meanwhile, according to Stoner that are quoted by T. Hani Handoko in [13] suggested that: "Management is the process of planning, organizing, directing, and monitoring efforts of the members of the organization and other organizations use resources to achieve organizational objectives that have been set." in particular in the context of education, Djam'an Satori in [13] provide an understanding of management education by using educational administrative term is defined as "the entire process of cooperation by utilizing all personnel and material resources are available and appropriate to achieve the educational goals set effectively and efficiently".

\section{Management of the Curriculum}

Management of the curriculum is the main substance in school management. The basic principle of this curriculum management is trying to make the learning process can run well, with the benchmark achievement by students and encourage teachers to develop and continuously improve their learning strategies. Stages in the school curriculum management is done through four stages: (a) planning, (b) organizing and coordination; (c) implementation, and (d) control.

\section{Management of Student}

Management in the management of student affairs is a basic principle (a) students should be treated as subjects and not objects, (b) the condition of the students are very diverse, in terms of physical condition, intellectual ability, socio-economic, interest and so on. Therefore we need a means of diverse activities, so that each student 
can develop optimally, (c) students are only motivated to learn, if they are enjoying what is taught, and (d) the development potential of the students not only about the cognitive, but also character / personality.

\section{4). Personnel Management}

There are four basic principles is also in personnel management, namely: (a) The school excels in developing human resources is a major component, (b) human resources can play optimally if managed well, so that support institutional goals; (c) organizational culture and atmosphere in school, and school managerial behavior affects the achievement of school development, and (d) management personnel in the school in principle to strive for every citizen to work together and support each other to achieve school goals. In addition to human resources, which is central in respect of personnel management is the control of the competence of the personnel at the school. Therefore, efforts to develop the competence of any school personnel to be absolutely necessary.

\section{5) Financial Management}

Financial problems at school especially with respect to school tips in tapping funds, school tips in managing funds, financial management associated with the school's annual program, how to administer the school fund, and how to monitor, control, and inspection. Financial management is the core of achieving efficiency and effectiveness. Therefore, the principle to be applied is the use of financial accountability and transparency of government, the public and other sources.

\section{6) Management Relationship with the Public School}

School as a community cannot be separated from where the school was located. Good relationships are built through relationship management with the public school, the school will facilitate superior in realizing its objectives. Schools can take place properly if the entire program gets support local communities and vice versa. In accord with Elsbree, Mc Nelly and Suriansyah in [13] that schools with public relations activities aimed at:

1. To improve the quality of children's learning and growing.

2. To rise community goals and improve the quality of community living

3. To develop understanding, enthusiasm and support for community program of public educations 4.

\section{Research Sites}

\section{Method}

The research was conducted in schools in Banda Aceh city excels both residential (boarding) and nonboarding. Is superior boarding senior high school (SMAN) 10 Fajar Harapan Banda Aceh and junior high school (SMP) 19 Pilot Banda Aceh. While the boarding school was not superior SMAN 1 Jeumpa Puteh Banda Aceh, SMAN 3 Banda Aceh, SMAN 4, and Banda Aceh.

\section{Methods and Techniques of Data Collection}

The goal to get a clear and complete picture of the character building strategies adopted by heads and teachers at the school ahead of Banda Aceh at the present time, the research method used is descriptive qualitative method. Research activities carried out for 4 months starting August 2012 until December 2012. Techniques to collect the data needed to answer the research questions are 1) direct observation of characterbuilding activities, 2) interviews to supplement the data obtained through observation and 3) analysis of the documentation. Respondents in this study were the principal, the vice principal areas of student, teacher-teacher, organization of student (OSIS) and students are selected based on the purpose of the study (purposive sapling). The data are collected and processed by qualitative analysis to ensure the validity of data credibility test research data with the old observation, trying to understand the data carefully, perform triangulation and discussions with colleagues. These steps correspond to what was raised [14] and Sugiyono namely: "That the test of credibility of qualitative research data include observations made by extension, increased diligence in research; triangulation; discussion with colleagues; negative case analysis, and member check".

\section{Results of the Study}

\section{Result and Discussion}

The results showed that schools in the city of Banda Aceh excel both boarding and non-boarding has conducted coaching character/personality of students by using strategies that are categorized as effective so that it can suppress or eliminate the deviant behavior of the students. It proved to lower cases of violent crime, delinquency, and student attendance should be handled by the teacher Guidance Counseling.

Judging from the achievement, pilot school students in Banda Aceh did not differ between superior boarding school with no boarding, especially from the National Examination and graduation rates achievements 
extracurricular. Obtaining any contest trophies fields of study, but one that is very proud that the winning school SMAN 10 Fajar Harapan is 2 years still survives as the first winner of Indonesia. The benchmarks used are academic achievement or value of National Examination (NE).

Strategies for building character/personality of students used by principals and teachers at the school ahead of Banda Aceh can be classified into 5 types: 1) Provides understanding of the character/personality of the students, 2) Developing Islamic culture in schools, 3) implement character education, 4) Provide exemplary, and 5) Provide penalties for violators of school discipline. Description of the application of each strategy coaching character/personality that were held in each of the winning schools can be stated as follows:

\section{Provide an Understanding of the Character/Personality of the Students}

One human trait of character / personality is a man who knows his true identity. Because the character building of students at the school ahead of Banda Aceh begins by teaching how to know who he was to the students. Beginning of each year new students equipped with self-knowledge and noble spirit which is predominantly delivered by religious teachers in turn, the principal, vice principal of student field.

While the problems associated with the behavior and attitude of the students of these schools more widely introduced by OSIS under the guidance of vice principal field of student affairs. Introduced to students the school rules, which are in demand behavior while in school and discipline. The first question posed to the students on "who he is". For what he was present at this school?, what the ultimate goal they want to achieve?, how to achieve that goal? and the like.

In an effort to help students know themselves, teachers, principals, school discipline, good attitudes, duties and obligations as a student, and a variety of provisions that apply in school, all the components involved. Religion teacher, principal, student council advisor, OSIS involved in character building activities give students, especially in terms of character/ personality well and motivate students to practice the new entry in the life of the school and also in the life at home and society.

Religious teachers in turn also provide an understanding of the nature of God made man, his obligations as a vicegerent on earth and bans. The school principal explained the school rules and sanctions to be imposed for violating the rules. Based on the results of the research data showed that coaching character/personality of the students of the schools winning more dominant approach religion especially in describing the character traits of a student. This strategy is very effective because by understanding the religious values of a student will know who he is and how he should behave in school, at home or in the community. With self-knowledge and its potential, he also knew who made him, and what his responsibility as a servant of God, how commendable behavior that should practiced.

Then the students described how the student profile that looks to the school, parents, and the community now and for the future. During a superior school the students are expected to present themselves as exemplary human beings, especially in day-to-day behavior. The hope is "a superior student in the mastery of science, technology, and skills, and character/personality.

On many occasions coaching principals and teachers to explain that one of the marks of students in character/personality is obedience to God in performing worship and discipline execute learning tasks to achieve high academic achievement. The issue of worship to God should not be ignored because it is the purpose of human created by God.

Finally, it can be concluded that the principals and teachers at the school ahead of Banda Aceh has given a fairly comprehensive understanding of the character/personality of the students through a holistic approach (religion) and the scientific approach. Positive impact on student behavior both boarding schools and nonboarding is not a student delinquency cases that require the handling of Guidance Counseling (GC) or involve parents.

\section{Developing Islamic Culture in Schools}

Coaching character/morality cannot be formally taught as subjects of mathematics, science or social science, because teaching material character/personality nuances of spiritual or psychological. Character values /morals are not focused on one subject but with all integrated in all subjects.

Learning character/morality is actually summed up in the creed of subjects the implementation of which referred to the character/characters. Then to develop character/ morality students should be introduced and familiarize teachers with implementing good behavior in life. Principals and teachers create school conditions (external setting) in schools that encourage students to familiarize Islamic habits.

Expected to grow externally through setting an Islamic school culture and encourage student's always commendable morals in school and outside of school as well. Character/ morals are expected to grow and develop in the students through a civilizing institution (school culture) is:

1. Discipline and obedience to worship

2. Love the cleanliness and beauty, 
3. Solidarity,

4. Manners,

5. Mutual respect,

6. Shame to do err

In building a school culture that supports the implementation of character/moral superior school students then prepare a variety of tools needed include:

1. School discipline

2. Places of worship and managers (Mushalla)

3. Trash and schedules mutual cooperation

4. School gardens and appeals boards or moral slogans

5. Extra-curricular activities with

6. Held a race hygiene routine

7. Note the mistakes made by students

Having regard to the culture of the school (school culture) are at the ready to support the emergence of the Islamic character of the students, it can be concluded that the superior schools in the city of Banda Aceh have been using the right strategy for building student character development through Islamic culture in the school. Student has always lived in a positive culture in the school, praised the students' character will be a culture for themselves and ultimately their self-consciously avoid in despicable character.

\section{a. Implementation of Character Education Through Special Forums}

In addition to the two strategies described above superior schools Banda Aceh also implement character education strategies that directly deal specifically with students. Targets to be achieved are spawned beings who always thought, remembrance, and act Islamically. The strategy adopted is to use every opportunity both in learning and extra-curricular activities.

These times are used for character education by both teachers want-any religious teacher is; spiritual coaching in the dorm, lecture dawn, day-to-day commemoration of the Islamic and national, such as warnings and Ascension of the Prophet's Birthday, the hero vows youth and others. For these activities are usually imported from the speakers outside so the student gets a new teacher with a style that pleases them.

For those who are not boarding schools also implemented character education through special activities in which all students attended the lecture briefly after zhuhur prayers. Sometimes given by religious teachers, principals sometimes and sometimes invited speaker from outside. In the era of the development of science and technology information so quickly, while the destruction of the values of the character/moral performed by the parties in a systemic and systematic either consciously or not, the effort to save the young generation from the dangers need to be designed and implemented effectively anyway.

\section{b. Provide Exemplary}

The results were obtained testimony that in executing coaching character/moral superior school students in the city of Banda Aceh is also used strategies to provide exemplary. So to implement this strategy requires schools to all school personnel, school principals, teachers, and other education personnel to perform as an exemplary figure/role model for students.

With all readiness of personnel to perform as a role model, students can directly mimic the character/behavior of the teachers, principals or other school personnel. The teacher will show up as being a professional teacher, the school principal as an exemplary leader and all school personnel deserve heard and imitated by students. Exemplary aspect, shown in the way they dress, how to greet a fellow teacher, the attitude is always friendly, attractive style of teaching students, pay attention to the students who have difficulty in following the lesson, not discriminatory, pious, polite in speech, and simple.

The results also provide data that, not all teachers and school personnel can excel present themselves as good role models while teaching in the classroom and outside the classroom performance. This has become one of the principal obstacles experienced in the implementation of development strategies on school students excel character. The most of the personnel are able to present themselves as the second parents of the students, the majority have not been able to play so small.

Strategy coaching character/personality by providing exemplary in living conditions today are very effective because the students and even teachers as role model or idol lost his life. Because the character/personality must be inculcated in students by demonstrating how should he perform as a student character. This strategy has been implemented in schools ahead of Banda Aceh, although not achieving optimal results.

\section{c. Providing Penalties for the Violation of the Provisions}

The results showed that although the school has made and disseminating the school rules, discipline boarding, training discipline, creating a school culture, and provide exemplary in order to develop students' 
character, but sanctions for students who violate still need to be enacted. It based on the observation that although the frequency is low but there is a student who commits an offense intentionally or because it was used.

These sanctions tailored to the types of errors made by students and their implementation governess subjects if his mistake was academic, and implemented by OSIS if fault comes to the rights and obligations of students are violated. Form of sanctions established by OSIS and usually that gets sanctions also accept because the sanctions provided always that will be useful for school. For example, picking up trash, mushalla cleaning, clean up parks and the like.

Based on the description of the data that has been stated above it can be concluded that the implementation of coaching character/personality of the superior schools of Banda Aceh has been carried out effectively by using a variety of strategies. Character building results conducted by the principal and the teachers showed very satisfactory results. Schools excel at Banda Aceh rare a matter relating to violence, crime or offense that requires principals to solve with the student's parents. Violation of school rules did occur, but on a small scale both the number and problem.

\section{Discussion}

Coaching character/personality or moral development lately becomes very frequent sticking to the surface and into the conversation at all forums and at all levels. This is the public reaction to the outbreak of the violence, crime and violation of law, ethics, and even religion by the students and youth in the community. Violations of law, ethics, and religion is often the case the school is not really something intentional by students but tends to as the phenomenon of "a kind of vacuum in the moral development of the students experienced life" [8]. Therefore, when given the sanctions they received with resignation, not fight or resist. This fact shows that within themselves there is a desire to reject the ethical values that apply to life and his school.

\section{Provide an Understanding of the Character/Personality of the Students}

The first step taken by superior schools in the city of Banda Aceh coaching character/ personality of the students is to provide an understanding of the character / personality of the students. By understanding the meaning of the character of the students will tend to practice in his life. This is consistent with what is asserted by [8] an initiator of character education as follows:

Parents today must encourage the growth of basic morality by teaching the younger generation directly or indirectly, so that they respect the moral values. The younger generation needs to be made aware of their responsibilities to live together with respect for basic values such as trust mutual trust, honesty, and a sense of social solidarity.

Strategies used by teachers in developing the character of students on the school excels city of Banda Aceh, is to apply the principles and methods of Islamic education as proposed by the Directorate of Religion Education, Ministry of Religious Affairs (2010: 70-71), namely:

Islamic education adhering to the principle of expediency, means that Islamic education should encourage students that learning is not merely to obtain rank 1 (which is achieved with the principle of mutual competition to outdo one another), but based on the principle of benefit, which is to be useful to humans others (khairunnasi anfa'uhum linnas). With this kind of learning the principles of the pupil is fully conditioned to not think of anyone else as a threat or an enemy to be defeated, conquered, oppressed, but always ready to develop cooperation with anyone, for the benefit of our fellow humans.

Application the principles of education outlined above will building good character in students, they will always practice good character traits such as discipline, honesty, comradeship, courtesy, mutual-respect prices, other students are not considered to be rivals or opponents but partner learning mutual benefit.

\section{Developing Islamic Culture in Schools}

Develop character/personality of students in schools in addition to superior Banda Aceh done by giving the notion of character/personality is also done by developing habits of good in school. This is very important as learning the character can not be done by just delivering course material to students, but through habituation or familiarization-habituation in school. Building a school culture especially Islamic culture is a very effective strategy for character education, meaning building a complexity of values, norms and ethical Islamic so accustomed to these values. Effectiveness of coaching character/personality through acculturation pretty good as confirmed Kroaber and Kluckhohn in [8] as follows:

Between personality and culture that there is a mutually beneficial interaction. In the personality development of the necessary culture and so on, the culture will be developed through these personalities. This 
is called circular causality between personality and culture. This shows us that education is not merely passive but cultural transformation necessary to develop a creative personality.

So the development of school culture/institutions is essential to the development of character/personality, but the condition of our schools more shackle creativity of the students.

Culture can be seen as a means of supporting the development of character in students because there are cultural signposts that can guide and direct students to always follow good behavior/moral commendable. This was stated by [15] that "Culture can be defined as: 1) the complexity of ideas, ideas, norms, and regulations in a society, 2) a pattern of behavior that has been deeply rooted in the community, 3) form the objects of human handiwork.

\section{Implementation of Character Education Through Special Forums}

In addition to giving the sense of character and strategy to build an Islamic school culture superior schools also implement character building of students through character education through coaching activities such as spiritual coaching in the dorm on Friday night, Yasin readings quran, lectures dawn, a short talk after the dhuhur prayer, and guidance through the day-to-day commemoration of the Islamic and national.

For these activities are usually brought in teachers/lecturers from outside than religious teacher in turns. It is very important because in the era of the development of science and technology information so quickly, while the destruction of the values of the character/moral performed by the parties in a systemic and systematic effort to save the young generation from the dangers need to be designed and implemented effectively anyway. Jams Wm, in [8] states that the need for character education, due to three things, namely:

First; weakening of family ties, the traditional family is the first teacher of every child, began to lose its function. Thus there was a vacuum in the moral development of the child's life,

Second, the negative trend in the lives of youth, today we are witnessing, especially in big cities fights between students, between villages fights, quarrels within the social and political organization, quarrels at meetings of intellectuals, it is the phenomenon of behavioral abnormalities youth,

Third, a revival of the need for ethical values. Now beginning to emerge a trend that people began to realize that there is wisdom in the community about the basic morality that is essential to the survival of society.

The character education strategies together in forums lecture attitude and personality of students will be nurtured towards good behavior and they were able to select and sort the disgraceful and reprehensible behavior.

\section{Provide Exemplary}

The results showed that the formation of character/personality in the superior schools of Banda Aceh was also carried out with exemplary delivery strategies to students. All personnel are required to appear as role models in their respective positions so that students can emulate their profile in performing their duties and dayto-day obligations.

Today many parents lack the time to serve their children, so that the child feels neglected by her parents. His parents sometimes cannot be a role model for her children. What does a head-winning principal city of Banda Aceh in order to develop students through the provision of exemplary character is quite effective and a positive impact on student behavior. This is consistent with the view of Thomas Lickona and Daniel Goleman which states that the task of the teacher becomes more crucial and decisive. According to him some heavy duty teachers should be implemented as follows:

1. Teacher should be a model and mentor as well as a learner in realizing of moral values in life at school.

2. Public schools should be a moral society. School is not merely to increase the intellectual capability, but honesty, truth, and devotion to humanity.

3. Practice moral discipline in the school. Morale is something that is restrictive means not just a descriptive of something good, but something that directs behavior and the mind to do well.

Through the provision of exemplary believed students have role models or if it could be a role model for student teachers in practice commendable behavior and avoid inappropriate behavior. One thing that was very influential on the character of the students' lives at school is the principal and teachers of moral discipline in the school.

\section{Providing Penalties for the Violation of the Provisions}

Although principals and teachers school excellence Banda Aceh has implemented coaching character with a variety of strategies, but still there are students who commit violations of all provisions. It requires schools to give sanction to the student as a warning, to make him aware and not to repeat the actions that deviate from the 
applicable provisions. The development of science and technology so fast, while the destruction of the character/moral occurs systemically and systematically. This requires efforts to save the young generation from the dangers need to be designed and implemented effectively anyway. Appropriate strategy is to prevent the occurrence of irregularities and impose sanctions for breaking the rules at school.

The ultimate objectives of fostering character/personality is a student, gave birth to an excellent student and always act and behave well towards God, himself, his parents, the community, and the environment.

\section{Conclusions}

\section{Conclusions and Recommendations}

a. In carrying out development character/personality of the students and the school head teachers of schools excel Banda Aceh has implemented strategies vary widely, namely 1) to give the sense of character/personality to the students, 2) developing a school culture are Islamic, 3) implement character education through special forums, 4) giving the example to the students, and 5) provide sanctions for students who violate school rules. The uses of these strategies have provided good results are characterized by the lack of crime and violence in schools.

b. Activities include the development of character/personality of the students at the school ahead of Banda Aceh implemented by integrating the values of character/ personality in all subjects so that all teachers are involved in the process of character building of students and is responsible for the success or failure of coaching character/personality of the students according with class and subjects who carried.

c. Accuracy of coaching strategies, compactness teachers and school personnel and the availability of adequate facilities for coaching character/personality, character building program/personality to excel in school is successful, this is indicated by the low number of violations of school rules and the crime that occurs in all schools excel. However, activities are still going on because there are a few obstacles that teachers cannot fully present themselves as role models for the students like.

\section{Recommendation}

a. Efficacy of strategy coaching character/personality on superior schools should be maintained and consequently implemented so as to guarantee every student who comes to school to students who have a superior character/personality those well suits the demands of religion, law and ethics are the accepted norm.

b. Teacher readiness to integrate the values of character/personality in subjects who carried an effective condition for building character/personality in superior school. It should continue to be implemented in order to shape the character of students can be maintained at a excellent school in Banda Aceh,

c. Slogans are installed in parks, school grounds, dormitories, prayer rooms and other places should always be updated writing, language and style of writing that has always attracted the attention of students to read and execute it.

Thus the conclusions and suggestions can be put forward that may be useful for building character/personality of students in all types and levels of education.

\section{Acknowledgements}

The author would like to thank profusely my friends for support and encouragement and who helped in the process of retrieval and data processing.

\section{Reference}

[1] Bhaktivedanta Swami Prabhupada, A., The Science of Self Realization. 1994: p. 189.

[2] Adimassana, Y., Ki Ageng Suryomentaran Tentang Citra Manusia 1986.

[3] Atmadi., e.a., Transformasi Pendidikan, Memasuki Millennium Ketiga, . 2000: p. 34

[4] Aceh, P.W.K.B., Forum Peningkatan Aqidah dan Pengamalan Ajaran-ajaran Islam. 2012.

[5] Arifin., H.M., Kapita Selekta Pendidikan, Islam dan Umum. 2004.

[6] Driyarkara, N., Tentang Pendidikan. 1980: p. 129.

[7] Montemayor, F., M,, , Ethics: The Philosophy of Life, . 1994: p. 11.

[8] Tilaar, H., Pendidikan, Kebudayaan dan Masyarakat Madani Indonesia 2004.

[9] Indonesia, D.P.d.K., Tentang Guru dan Dosen. 2005.

[10] Buchari., M., Transformasi Pendidikan Untuk Meremajakan Budaya dan Pola Hidup Bangsa. 2007.

[11] Barbara A. Lewis, Character Building untuk Remaja. 2004.

[12] Atmadi., S., Transformasi Pendidikan, Memasuki Millennium Ketiga. 2002: p. 38-39.

[13] Mulyasa, Manajemen Berbasis Sekolah, konsep, strategi dan implementasi 2007.

[14] John. P. Miler., Cerdas di Kelas Sekolah Kepribadian 2002.

[15] Koentjaraningrat, Kebudayaan, Mentalitas dan Pembangunan 1986. 